\title{
An indirect effect of COVID-19 pandemic: Increased pediatric perforated appendicitis rate due to delayed admission
}

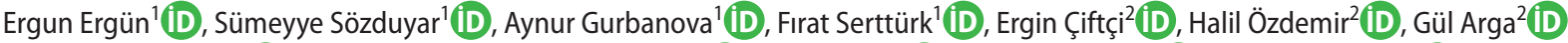 \\ 1 Department of Pediatric Surgery, Ankara University Faculty of Medicine, Ankara, Turkey \\ ${ }^{2}$ Division of Pediatric Infectious Disease, Ankara University Faculty of Medicine, Ankara, Turkey \\ ${ }^{3}$ Department of Infectious Diseases and Clinical Microbiology, Ankara University Faculty of Medicine, Ankara, Turkey \\ ${ }^{4}$ Department of Anesthesia and Reanimation, Ankara University Faculty of Medicine, Ankara, Turkey \\ ${ }^{5}$ Division of Pediatric Radiology, Ankara University Faculty of Medicine, Ankara, Turkey \\ ${ }^{6}$ Division of Pediatric Emergency, Ankara University Faculty of Medicine, Ankara, Turkey
} Hatice Kübra Konca ${ }^{2}$ D, Güle Çınar ${ }^{3}$, İrem Akdemir Kalkan ${ }^{3}$ D] Ezgi Gülten ${ }^{3}$ D, Özlem Selvi Can ${ }^{4}$ D, Birsel Şen Akova ${ }^{5}$ D, Ömer Suat Fitöz ${ }^{5}$ D,

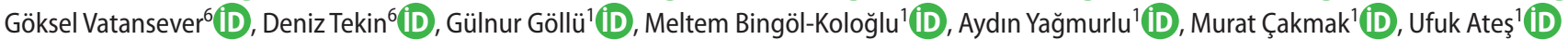

\section{ABSTRACT}

Objective: Appendicitis is a common surgical emergency among children. The coronavirus pandemic affected the system of hospitals more than any other field, and great amount of people were concerned about visiting the hospitals for any reason. In this study, it was aimed to evaluate the profile of appendicitis by emphasizing perforated and acute appendicitis in the pandemic period and to compare the rates with previous three years.

Material and Methods: Charts of the children who underwent laparoscopic appendectomy due to appendicitis between March 11-September 30 between 2017-2020 were retrospectively analyzed in terms of demographic data, duration of symptoms, duration between hospital admission and surgery, radiologic imaging and perioperative outcomes.

Results: This study includes 467 children who underwent laparoscopic appendectomy. There were 97 procedures in 2020, 111 in 2019,146 in 2018 and 113 in 2017. Multiple comparison tests revealed that age did not show difference; but onset of symptoms in admission ( $p=0.004)$, hospitalization time before surgery $(p<0.001)$, total hospitalization time $(p<0.001)$ showed statistically significant difference between years. Pairwise comparisons showed that these parameters were increased in 2020 compared to other years. Perforated appendicitis rate was significantly increased in 2020 when compared to previous years.

Conclusion: Although there is no direct relation between appendicitis and COVID-19 infection in the current knowledge, perforated appendicitis was found to be increased in children during the COVID pandemic. Reason of the higher rate of perforated appendicitis may be multifactorial; however, the pandemic appears to have a role in increased morbidity in children with appendicitis indirectly due to delay of hospital admissions.

Keywords: Appendicitis, child, coronavirus, pandemic, pediatric surgery

Cite this article as: Ergün $E$, Sözduyar $S$, Gurbanova $A$ Serttürk F, Çiftçi E, Özdemir $H$, et al. An indirect effect of COVID-19 pandemic: Increased pediatric perforated appendicitis rate due to delayed admission. Turk J Surg 2021 37 (4): 318-323.

\section{Corresponding Author}

Ergun Ergün

E-mail: drergunergun@gmail.com

Received: 11.03 .2021

Accepted: 06.10 .2021

Available Online Date: 31.12 .2021

( Copyright 2021 by Turkish Surgical Society Available online at www.turkjsurg.com

DOI: 10.47717/turkjsurg.2021.5277

\section{INTRODUCTION}

Appendicitis is a common surgical emergency among children (1). It may present as acute appendicitis (AA) or perforated appendicitis (PA). AA constitutes 1-8\% of the cases among children admitted to the emergency department with complaints of abdominal pain (2). PA is not as common as AA, but it remains to contain majority of appendicitis cases in children under three years of age (1).

Widely accepted treatment of AA includes laparoscopic or open appendectomy, but recently studies on non-operative treatment with parenteral antibiotics have been documented $(1,3)$. Non-operative treatment has not been established yet in PA except appendiceal plastron in which the peritoneal dissemination of intestinal content is limited by the omentum and intestines. Morbidity of PA is much higher than AA, as expected (4). It also has the risks of increased hospital stay, longer use of parenteral antibiotics, sepsis and even death (5). 
As we all know, the coronavirus pandemic affected the system of hospitals more than any other field. Outpatient clinics nearly stopped for few months in our country as well as others, and all attention was canalized to emergency and infectious diseases. "Stay at home" policy was also valid for patients in the need of routine controls, and at some point, a great amount of people were concerned about visiting the hospitals for any reason even though the situation was urgent or necessary.

In these extraordinary conditions, we thought that PA rate might have increased due to multiple reasons such as delayed apply to hospital, immunocompromised status of the child, children's tendency to hide the pain from their parents due to anxiety, experiencing difficulties of reaching healthcare, and etc. Even though we could not evaluate all these factors; the basic hypothesis of the study was that PA incidence might be higher in pandemic conditions when compared to the same periods of past years independently from patient age.

\section{MATERIAL and METHODS}

The study was performed in adherence to the latest version of Declaration of Helsinki, and ethics approval was obtained.

\section{Dates}

March 11, 2020 was accepted as the set point for the study as it was the day when the first case infected with coronavirus was publicized in Turkey. Charts of the children who underwent laparoscopic appendectomy due to appendicitis between March 11-September 30 were retrospectively analyzed for the years of 2017, 2018, 2019 and 2020.

\section{Patients}

Children who underwent LA were included in this study. Since the beginning of the pandemic, all children underwent COVID-19 PCR test, and they were questioned for contact with people infected with COVID-19 preoperatively. The COVID-19 PCR tests ensued in between 6-24 hours, and meanwhile intravenous antibiotherapy was administered to the children while awaiting the PCR test results after diagnosis of appendicitis. Children with positive PCR test and suspicious contact of COVID-19 were managed conservatively and they were excluded from the study $(n=6)$. Children with additional diseases which may cause prolonged hospitalization were excluded. Incidental and interval appendectomies were also excluded.

\section{Surgical Method}

All children with a prediagnosis of appendicitis- PA or AA underwent LA with three ports in case of absence of suspicious contact of COVID-19 or COVID-19 PCR positivity.

\section{Data}

Demographic data of the children were recorded. Presence of appendiceal perforation was determined according to operation notes or histopathologic examination. Perforated appendi- citis was defined as a visible hole on the appendix wall and/or fecaliths in the abdominal cavity during the surgery. A hole on the appendix wall in pathologic examination was also accepted perforated appendicitis. Hospitalization before surgery was defined as the period from hospital admission to surgery. Hospital stay was described as the period from surgery to discharge. PA rates were also recorded.

Evaluation: PA rates in the same periods of 2017 to 2019 were evaluated combinedly and separately for each year and compared to 2020.

\section{Statistical Analysis}

Before comparative analysis, continuous variables were evaluated for normal distribution by histogram graphs and Kolmogorov-Smirnov test. Variables (age, total hospitalization time, hospitalization before surgery) which did not have normal distribution were evaluated by the Kruskal-Wallis test, and normally distributed data were analyzed by Anova test in terms of the presence of difference between years. Post-hoc tests were performed to evaluate the difference between groups. Chi-Square test was conducted for association of years and diagnosis. $p$ value $<0.05$ was considered statistically significant. Benferoni correction was used for multiple comparisons. Statistical Package for the Social Sciences (SPSS), version 16.0 (IBM ${ }^{\oplus}$, Chicago, USA) was used for analysis.

\section{RESULTS}

This study included 467 children who underwent LA due to AA or PA. One hundred and seventy-four (37.3\%) were females and 293 (62.7\%) were males. Mean age of the children was 11.4 years (1-18 years). There were 97 LA procedures in 2020, 111 in 2019, 146 in 2018 and 113 in 2017. Mean onset of symptoms at admission was 29.5 hours (4 hours-14 days). Mean hospitalization time before surgery and total hospitalization time were 9.5 hours (1-24 hours) and 1.7 days (1-13 days), respectively. Multiple comparison tests revealed that ages of the children in each year were not different; but time between onset of the symptoms and hospital admission, hospitalization time before surgery and total hospitalization time showed statistically significant difference between the years (Table 1). Pairwise comparisons showed that these variables increased in 2020 compared to other years (Table 2). PA rate was significantly increased in 2020 compared to previous years (Table 3, Figure 1). PA diagnosis on ultrasound was concordant with intraoperative findings for 18 of 30 children for perforated appendicitis in 2020, 6/13 in 2019, 14/18 in 2018 and 5/13 in 2017, and no difference was found between years statistically ( $(\mathrm{m}=0.117$ ) (Table 4).

\section{DISCUSSION}

First COVID-19 case was reported from China at the end of 2019, and the disease rapidly spread all around the world in few months and was declared as a pandemic by WHO in March 2020 (6). In Turkey, the first COVID-19 case was detected on March 11, 
Increased perforated appendicitis rates in children during COVID-19 pandemic

Table 1. Multigroup comparisons between years

\begin{tabular}{|c|c|c|c|c|c|c|c|c|}
\hline \multirow{2}{*}{$\begin{array}{l}\text { Years } \\
\text { Variables }\end{array}$} & \multicolumn{2}{|c|}{ Age (year) } & \multicolumn{2}{|c|}{$\begin{array}{c}\text { Onset of symptoms time at } \\
\text { admission (hours) }\end{array}$} & \multicolumn{2}{|c|}{$\begin{array}{l}\text { Hospitalization before } \\
\text { surgery (hours) }\end{array}$} & \multicolumn{2}{|c|}{ Total hospitalization (days) } \\
\hline & Mean(SD) & $p$ & Mean (SD) & $p$ & Mean (SD) & $p$ & Mean (SD) & $p$ \\
\hline $2020(n=97)$ & $11.6(3.7)$ & \multirow{4}{*}{0.784} & $40(38.8)$ & \multirow{4}{*}{0.04} & $18.3(7.1)$ & \multirow{4}{*}{$<0.001$} & $1.9(0.2)$ & \multirow{4}{*}{$<0.001$} \\
\hline $2019(n=111)$ & $11.8(3.5)$ & & $26.6(24.0)$ & & $7.6(2.0)$ & & $1.7(1.3)$ & \\
\hline $2018(n=146)$ & $11.4(4.0)$ & & $28.6(26.3)$ & & $6.7(1.7)$ & & $1.7(1.6)$ & \\
\hline $2017(n=113)$ & $10.8(4.0)$ & & $24.6(15.6)$ & & $7.2(1.8)$ & & $1.6(1.07)$ & \\
\hline
\end{tabular}

Table 2. Pairwise comparisons for 2020 vs 2019, 2018 and 2017

\begin{tabular}{|l|c|c|c|c|c|c|}
\hline \multirow{2}{*}{ Variables } & \multicolumn{2}{|c|}{$\begin{array}{c}\text { Onset of symptoms time at } \\
\text { admission (hours) }\end{array}$} & \multicolumn{2}{c|}{$\begin{array}{c}\text { Hospitalization before surgery } \\
\text { (hours) }\end{array}$} & \multicolumn{2}{c|}{ Total hospitalization (days) } \\
\hline Years & Mean & $\mathbf{p}$ & Mean & $\mathbf{p}$ & Mean & $\mathbf{p}$ \\
\hline 2020 vs 2019 & $40-26.6$ & 0.002 & $18.3-7.6$ & $<0.001$ & $1.9-1.7$ & $<0.001$ \\
\hline 2020 vs 2018 & $40-28.6$ & 0.008 & $18.3-6.7$ & $<0.001$ & $1.9-1.7$ & $<0.001$ \\
\hline 2020 vs 2017 & $40-24.6$ & $<0.001$ & $18.3-7.2$ & $<0.001$ & $1.9-1.6$ & $<0.001$ \\
\hline
\end{tabular}

Table 3. Perforated appendicitis rates (2020 vs 2019, 2018 and 2017 respectively)

\begin{tabular}{|l|c|c|c|}
\hline \multicolumn{2}{|c|}{ Years } & Perforated appendicitis rate (\%) (2020 vs year) & $\mathbf{p}$ \\
\hline \multirow{3}{*}{2020} & 2017 & $30 / 11$ & 0.001 \\
\cline { 2 - 4 } & 2018 & $30 / 12$ & 0.001 \\
\cline { 2 - 4 } & 2019 & $30 / 12$ & 0.001 \\
\hline
\end{tabular}

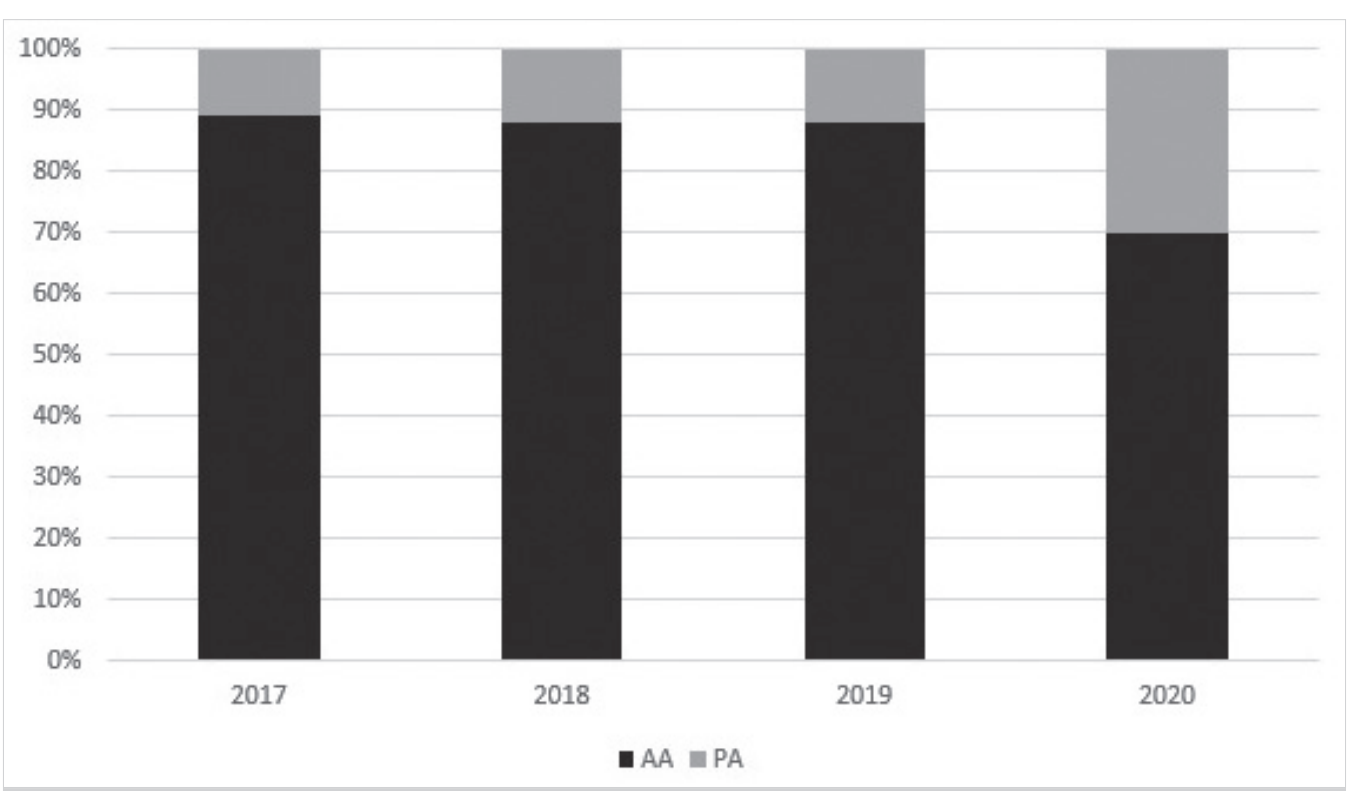

Figure 1. Rates of acute and perforated appendicitis.

2020 and increased by days (7). The disease affect children as well, but in contrary with adult population, they usually stay asymptomatic (8). Surveillance data from Turkey has revealed that $0.8 \%$ of children had severe disease (7). Despite Multisystem In- flammatory Syndrome (MISC) which was described in children after COVID-19 infection; they still seem to be less symptomatic and fatal comparing to adults $(7,9)$. 
Table 4. Ultrasound/Intraoperative perforation correlation

\begin{tabular}{|l|c|c|}
\hline Year & Ultrasound prediction rate of PA (\%) & p \\
\hline 2020 & 60 & 0.117 \\
\hline 2019 & 46 & \\
\hline 2018 & 78 & \\
\hline 2017 & 38 & \\
\hline
\end{tabular}

The primary outcome of the study was to find out whether PA rates increased in pediatric population during the COVID pandemic. With similar means of ages in children in the abovementioned years, PA rates was found to be increased in 2020 compared to prior years. Onset of symptoms at admission, total hospitalization time, time before surgery were also higher in 2020.

Conventionally, perforation of the appendix is considered to occur within 24 to 36 hours after the onset of symptoms (10). PA consists approximately $20 \%$ of children with appendicitis aged 10-17 years, and it is more common in younger children (10). Delayed presentation is the most important factor leading PA, and PA rates increases linearly with duration of symptoms $(9,11)$. In the present study, despite the fact that age of the patients, which is a risk factor for increased PA rates, was not different between years, PA rates were found significantly increased in 2020 compared to previous three years. Duration of symptoms in admission was higher than prior years (40 hours vs 26.6, 28.6, 24.6 in 2020, 2019, 2018, 2017, respectively, $p=0.04$ ). Total hospitalization time was also increased in this period, as expected. In concordant to present study, Fisher et al. have reported that PA rates was increased during 10 weeks of outbreak which can reflect the acute period of pandemic, comparing to their earlier practice in New York City (9). Parents' concerns of exposure to COVID-19 in hospital may lead to delay presentation of children with appendicitis. Even though COVID-19 cases have reduced, and limited normalization policies have been mentioned in Turkey, in the tenth month of pandemic, delayed apply to hospital seems to be an important problem that may have caused increased morbidity and prolonged hospitalization in children with appendicitis.

As a result of waiting for the COVID PCR test results for the operation, time before surgery was longer in 2020 compared to prior years. We evaluated duration of symptoms and ultrasound findings of children in admission for appendicitis suspicion to distinguish whether high PA rates arose from preoperative waiting time for PCR results or delayed apply. When the prediction rates of perforation via ultrasonography were analyzed for each year, it was found that there was not a statistically significant difference in 2020 with other years $(p=0.117)$. Regarding these data, we concluded that waiting for COVID PCR tests after sonographic evaluation is not related to the increase in PA rates.
Comparison of sonographic evaluation with intraoperative findings revealed that each year sonographic evaluation may miss some amount of PA. Excluding this waiting time duration lead uled correlate the increase in PA with delayed apply to the hospital. Mean time before surgery was 18.7 hours in 2020 and it was longer compared to years before the COVID-19 pandemic (7.6 hours, 6.7 hours, 7.2 hours in 2019, 2018, 2017 respectively, $p<0.001)$. Given the present data, it seems feasible and harmless to wait for confirmation of COVID-PCR negativity to prevent virus exposure to airway providers and surgical team during the airway management and surgery.

Clinical features of COVID-19 in children include fever and cough, gastrointestinal symptoms; however, most of the infected children appear to be asymptomatic (12). Furthermore, gastrointestinal manifestations may develop both in COVID-19 infection and appendicitis $(9,10,12)$. It may also confuse the physicians in this unusual conditions. Thus, we strongly recommend to wait for PCR results in children planned to undergo appendectomy procedure.

Non-operative management was described for non-perforated appendicitis in children with a success rate of 58\%-82 $(13,14)$. Interval appendectomy and non-operative management have been discussed even in complicated appendicitis by some authors $(15,16)$. Kvasnovsky et al. have reported experience of non-operative management for appendicitis with a success rate of $86 \%$ during the pandemic in New York City and they found no difference in length of hospital stay between children who were managed non-operatively and children who underwent surgery due to simple appendicitis (17). The safety of anesthesia in patients with positive PCR for COVID-19 is unclear, but early reports suggest a possible relation with increased perioperative complications $(18,19)$. In case of proven or high risk of COVID-19 infection which is concomitant to appendicitis, we strongly recommend considering non-surgical treatment as an option for both; the child and the surgical team.

Retrospective nature of the study is one of the most significant limitations. Also, our clinical observation on increase of PA rates in this period may cause bias even though the analysis of the data was performed by two separate researchers who were blinded to the years. Although same months of the years were selected for elimination of seasonal variability of PA, usage of uncontrolled data from the hospital database may decrease the 
veracity of the data, and it was not possible to reach out all parents and check the medical histories of children. Even though the number of the patients was satisfactory, the analysis was based on timing but not very detailed in other aspects. Thus, it was not possible to evaluate other reasons that may have played role in appendiceal perforation. Also, perforation prediction rates were basically based on sonographic imaging which may be classified as a subjective imaging method.

\section{CONCLUSION}

PA rates seem to be increased in pandemic conditions. In addition, duration of symptoms before hospital admission was higher in this period. Hospital stays were longer due to waiting for PCR tests, but it seems it did not increase PA rate much more than previous years.

Ethics Committee Approval: This study approval was obtained from Ankara University Human Researches Ethical Committee (Decision No: i1-6721, Date: 28.01.2021)

Peer-review: Externally peer-reviewed.

Author Contributions: Concept - All of authors; Design - All of authors; Supervision - All of authors; Data Collection and/or Processing - All of authors; Analysis and/or Interpratation - All of authors; Literature Review - All of authors; Writing Manuscript - All of authors;Critical Reviews - All of authors.

Conflict of Interest: The authors have no conflicts of interest to declare.

Financial Disclosure: The authors declared that this study has received no financial support.

\section{REFERENCES}

1. Rentea RM, St. Peter SD. Pediatric appendicitis. Surg Clin North Am 2017; 97(1), 93-112. [CrossRef]

2. Scholer SJ, Pituch K, Orr DP, Dittus RS. Clinical outcomes of children with acute abdominal pain. Pediatrics 1996; 98(4 Pt 1), 680-5. [CrossRef]

3. López JJ, Deans KJ, Minneci PC. Nonoperative management of appendicitis in children. Curr Opin Pediatr 2017; 29(3): 358-62. [CrossRef]

4. Gerall CD, DeFazio JR, Kahan AM, Fan W, Fallon ME, Middlesworth W, et al. Delayed presentation and sub-optimal outcomes of pediatric patients with acute appendicitis during the COVID-19 pandemic. J Pediatr Surg 2021; 56(5): 905-10. [CrossRef]

5. Schmidt YM, Wendling-Keim D, von Schweinitz D, Hubertus J, Berger M. Prophylactic drain placement in childhood perforated appendicitis: Does spillage matter? Front Pediatr 2020; 8: 588109. [CrossRef]
6. World Health Organization. Novel Coronavirus (2019-NCoV); 2020. [CrossRef]

7. Tezer H, Bedir Demirdağ T. Novel coronavirus disease (COVID-19) in children. Turk J Med Sci 2020; 50(SI-1): 592-603. [CrossRef]

8. She J, Liu L, Liu W. COVID-19 epidemic:Disease characteristics in children. J Med Virol 2020; 92(7): 747-54. [CrossRef]

9. Fisher JC, Tomita SS, Ginsburg HB, Gordon A, Walker D, Kuenzler KA. Increase in pediatric perforated appendicitis in the New York City metropolitan region at the epicenter of the COVID-19 outbreak. Ann Surg 2021; 273(3): 410-5. [CrossRef]

10. Pearl RH, Hale DA, Molloy M, Schutt DC, Jaques DP. Pediatric appendectomy. J Pediatr Surg 1995; 30(2): 173-8. [CrossRef]

11. Narsule CK, Kahle EJ, Kim DS, Anderson AC, Luks FI. Effect of delay in presentation on rate of perforation in children with appendicitis. Am J Emerg Med 2011;29(8): 890-3. [CrossRef]

12. Balasubramanian S, Rao NM, Goenka A, Roderick M, Ramanan AV Coronavirus Disease 2019 (COVID-19) in children - What we know so far and what we do not. Indian Pediatr 2020; 57(5): 435-42. [CrossRef]

13. Caruso AM, Pane A, Garau R, Atzori P, Podda M, Casuccio A, et al. Acute appendicitis in children: Not only surgical treatment. J Pediatr Surg 2017; 52(3): 444-8. [CrossRef]

14. Georgiou R, Eaton S, Stanton MP, Pierro A, Hall NJ. Efficacy and safety of nonoperative treatment for acute appendicitis: A meta-analysis. Pediatrics 2017; 139(3): e20163003. [CrossRef]

15. Zhang HL, Bai YZ, Zhou X, Wang WL. Nonoperative management of appendiceal phlegmon or abscess with an appendicolith in children. J Gastrointest Surg 2013; 17(4): 766-70. [CrossRef]

16. González MC, Rodríguez JCB, Moore EH, Atanay DA. Predictors of recurrent appendicitis after non-operative management of children with perforated appendicitis presenting with an appendicular inflammatory mass. Arch Dis Child 2014; 99(2): 154-7. [CrossRef]

17. Kvasnovsky CL, Shi Y, Rich BS, Glick RD, Soffer SZ, Lipskar AM, et. al. Limiting hospital resources for acute appendicitis in children: Lessons learned from the U.S. epicenter of the COVID-19 pandemic. J Pediatr Surg 2021; 56(5): 900-04. [CrossRef]

18. Chen R, Zhang Y, Huang L, Cheng Bi-Heng, Xia Zhong-Yuan, Meng Qing-Tao. Safety and efficacy of different anesthetic regimens for parturients with COVID-19 undergoing Cesarean delivery: a case series of 17 patients. Can J Anaesth 2020; 67(6): 655-63. [CrossRef]

19. Lei S, Jiang F, Su W, Chen C, Chen J, Mei W, et al. Clinical characteristics and outcomes of patients undergoing surgeries during the incubation period of COVID-19 infection. EClinical Medicine 2020; 21: 100331. [CrossRef] 


\section{ORIJINAL ÇALIŞMA-ÖZET}

Turk J Surg 2021; 37 (4): 318-323

\section{COVID-19 pandemisinin indirekt etkisi: Çocuklarda geç başvuruya bağlı perfore apendisit sayısında artış}

Ergun Ergün', Sümeyye Sözduyar', Aynur Gurbanova' ', Fırat Serttürk', Ergin Çiftçi', Halil Özdemir², Gül Arga², Hatice Kübra Konca², Güle Çınar ${ }^{3}$, İrem Akdemir Kalkan ${ }^{3}$, Ezgi Gülten ${ }^{3}$, Özlem Selvi Cann ${ }^{4}$ Birsel Şen Akova ${ }^{5}$, Ömer Suat Fitöz ${ }^{5}$, Göksel Vatansever ${ }^{6}$, Deniz Tekin ${ }^{6}$, Gülnur Göllü', Meltem Bingöl-Koloğlu' ${ }^{1}$ Aydın Yağmurlu', Murat Çakmak', Ufuk Ateş'

${ }^{1}$ Ankara Üniversitesi Tıp Fakültesi, Çocuk Cerrahisi Anabilim Dalı, Ankara, Türkiye

${ }^{2}$ Ankara Üniversitesi Tıp Fakültesi, Çocuk Enfeksiyon Hastalıkları Bilim Dalı, Ankara, Türkiye

${ }^{3}$ Ankara Üniversitesi Tıp Fakültesi, Enfeksiyon Hastalıkları Klinik Mikrobiyoloji Anabilim Dalı, Ankara, Türkiye

${ }^{4}$ Ankara Üniversitesi Tıp Fakültesi, Anesteziyoloji ve Reanimasyon Anabilim Dalı, Ankara, Türkiye

${ }^{5}$ Ankara Üniversitesi Tıp Fakültesi, Çocuk Radyolojisi Bilim Dalı, Ankara, Türkiye

${ }^{6}$ Ankara Üniversitesi Tıp Fakültesi, Çocuk Acil Bilim Dalı, Ankara, Türkiye

\section{ÖZET}

Giriş ve Amaç: Apandisit, çocuklarda yaygın bir acil cerrahi girişim sebebidir. Koronavirüs pandemisi, herhangi bir alandan daha çok hastane sistemlerini etkilemiş ve insanların birçoğu herhangi bir sebep ile hastane başvuruları yapmak konusunda tereddütte kalmışlardır. Bu çalışmanın amacı, pandemi boyunca karşılaşılan perfore ve akut apandisit olgularının üzerinde durarak apandisit profillerini değerlendirmek ve önceki üç yıla ait oranlarla karşılaştırma yapmaktır.

Gereç ve Yöntem: 11 Mart - 30 Eylül, 2017-2020 tarihleri arasında apandisit sebebiyle laparoskopik apendektomi uygulanan çocukların dosyaları, demografik veriler, bulguların süresi, hastaneye yatış ve cerrahi arasında geçen süre, radyolojik görüntüleme ve perioperatif sonuçlar bakımından retrospektif olarak incelendi.

Bulgular: Çalışmaya laparoskopik apendektomi uygulanan 467 çocuk hasta dahil edildi. 2020 yılında 97, 2019 yılında 11, 2018 yılında 146 ve 2017 yılında 113 cerrahi işlem mevcuttu. Çoklu karşılaştırma testleri yaşın farklılık göstermediğini ancak yıllar arasında istatiksel olarak anlamlı farklııkların başvuruda bulguların başlangıcı $(p=0,004)$, ameliyat öncesi hastanede yatış süresi $(p<0,001)$ ve toplam hastanede yatış süresi $p<$ 0,001 ) değişkenlerinde olduğunu ortaya koydu. İkili karşılaştırmalar bu parametrelerin diğer yıllara oranla 2020 yılında arttığını gösterdi. Perfore apandisit oranı, diğer yıllara kıyasla 2020 yılında anlamlı derecede yüksek bulundu.

Sonuç: Mevcut bilgiler ışığında COVID-19 enfeksiyonu ve apandisit arasında doğrudan bir ilişki bulunmasa da perfore apandisit çocuk olgularının COVID-19 pandemisi süresince arttığı bulundu. Perfore apandisitteki bu yüksek oranın sebebi çok bileşenli olsa da pandemi döneminde hastaneye başvuruların gecikmesi ile birlikte pandeminin apandisitli çocuklarda dolaylı olarak morbiditeyi artırıcı bir rolü olduğu dikkati çekmiştir.

Anahtar Kelimeler: Apandisit, çocuk, koronavirüs, pandemi, pediatrik cerrahi

Doi: $10.47717 /$ turkjsurg.2021.5277 